\title{
Soybean growth affected by seeding rate and mineral nitrogen
}

\author{
Flávia Werner ${ }^{1}$, Alvadi A. Balbinot Junior ${ }^{2}$, André S. Ferreira ${ }^{1}$, \\ Marcelo A. de A. e Silva ${ }^{1}$, Henrique Debiasi ${ }^{2} \&$ Julio C. Franchini ${ }^{2}$ \\ ${ }^{1}$ Universidade Estadual de Londrina/Centro de Ciências Agrárias/Departamento de Agronomia. Londrina, PR. E-mail: flawerner6@gmail.com \\ (Corresponding author); andresampaioferreira@gmail.com; aguiaresilva@uel.br \\ ${ }^{2}$ Empresa Brasileira de Pesquisa Agropecuária/Embrapa Soja. Londrina, PR. E-mail: alvadi.balbinot@embrapa.br; henrique.debiasi@embrapa.br; \\ julio.franchini@embrapa.br
}

\section{Key words:}

Glycine max L.

plant spatial arrangement nitrogen fertilization

grain yield

\begin{abstract}
A B S T R A C T
This study aimed to evaluate the effect of seeding rates and nitrogen $(\mathrm{N})$ fertilization on plant growth in soybean cultivar with indeterminate growth habit. Two experiments were conducted in the 2013/14 and 2014/15 growing seasons, in a complete block design with split-plot scheme and six replicates. Four seeding rates (150, 300, 440 and 560000 viable seeds ha $\left.{ }^{-1}\right)$ and two $\mathrm{N}$ doses $\left(0\right.$ and $\left.45 \mathrm{~kg} \mathrm{ha}^{-1}\right)$ were allocated in the plots and subplots, respectively. The cultivar NK7059 RR was used. The following traits were assessed: leaf, stem and total shoot dry matter, leaf/stem dry matter ratio, stem and leaf N content, SPAD index, plant height, first pod height, number of branches per plant and grain yield. Soybean growth is not affected by the interaction of plant density and mineral $\mathrm{N}$ fertilization. Higher seeding rates increase plant dry matter in the initial development stages and reduce leaf/ stem ratio and the number of branches per plant. The effects of $\mathrm{N}$ fertilization on soybean growth vary between growing seasons, but do not affect grain yield, even considering a wide range of seeding rates.
\end{abstract}

\section{Palavras-chave:}

Glycine max L. arranjo espacial de plantas adubação nitrogenada produtividade de grãos

\section{Crescimento de plantas de soja influenciado pela densidade de semeadura e nitrogênio mineral}

\section{R E S U M O}

Neste trabalho o objetivo foi avaliar o efeito de densidades de semeadura e adubação nitrogenada sobre o crescimento de plantas de soja em cultivar com tipo de crescimento indeterminado. Dois experimentos foram conduzidos nas safras 2013/14 e 2014/15 com delineamento de blocos casualizados em parcelas subdivididas e seis repetições. Nas parcelas foram alocadas quatro densidades de semeadura $\left(150,300,440\right.$ e 560 mil sementes viáveis ha $\left.{ }^{-1}\right)$ e nas subparcelas dois níveis de nitrogênio $\left(0\right.$ e $\left.45 \mathrm{~kg} \mathrm{~N} \mathrm{ha}^{-1}\right)$. A cultivar de soja utilizada foi a NK7059 RR. Foram avaliados a massa seca de caules, folhas e total, relação folha/caule, o teor de nitrogênio nas folhas e no caule, índice SPAD, altura de plantas e da inserção da primeira vagem, número de ramos por planta e produtividade de grãos. O crescimento de plantas de soja não é afetado pela interação da densidade de semeadura e a adubação nitrogenada mineral. O aumento da densidade de semeadura incrementa a massa seca de plantas nas fases iniciais de desenvolvimento e reduz a relação folha/caule e o número de ramos por planta. O efeito da adubação nitrogenada no crescimento das plantas é variável entre as safras mas não aumenta a produtividade mesmo considerando ampla variação de densidade de semeadura. 


\section{INTRODUCTION}

Plant growth and crop yield are determined by the genotype, environment and the interaction between these two factors. Management practices, such as sowing period, choice of the cultivar and the spatial arrangement of the plants may alter growth and grain yield (Mauad et al, 2010; Procópio et al., 2014).

In Brazil, many studies have been conducted to adjust the density of soybean plants in order to increase grain yield (Ludwig et al., 2011; Balbinot Júnior et al., 2015; Silva et al., 2015). However, there are few studies considering cultivars with indeterminate growth habit, development cycle shorter than 120 days and plants with low size and compact architecture - attributes increasingly desired in soybean genetic breeding programs (Souza et al., 2010). Another factor that influences soybean growth and yield is the supply of nitrogen $(\mathrm{N})$. For each ton of grains produced, the crop demands about $80 \mathrm{~kg}$ of N (Roekel \& Purcell, 2014). Despite the high N demand by soybean, studies have demonstrated that biological $\mathrm{N}$ fixation, along with its mineralization in soil organic matter, can supply the necessity of the crop without the need for complementary $\mathrm{N}$ fertilization (Campo et al., 2009).

The interaction of seeding rate and $\mathrm{N}$ fertilization in the soybean crop, considering cultivar with indeterminate growth habit, has been little studied in Brazil, thus, it is relevant to verify whether there is any interaction between seeding rate and $\mathrm{N}$ fertilization that brings agronomic benefits. Given the above, this study aimed to evaluate the effect of seeding rates and mineral $\mathrm{N}$ fertilization on the growth of a soybean cultivar with indeterminate growth habit.

\section{Material ANd Methods}

Two experiments were conducted in the 2013/14 and 2014/15 growing seasons, at the Experimental Farm of Embrapa Soybean, in Londrina-PR, Brazil (231' S; $51^{\circ} 11^{\prime} \mathrm{W}$; $620 \mathrm{~m}$ ) using the same experimental area. The soil was classified as distroferric Red Latosol (Santos et al., 2006) and showed the following attributes in the layer of $0-20 \mathrm{~cm}$, before the experiment: $21.4 \mathrm{~g} \mathrm{dm}^{-3}$ of organic matter; 4.9 of $\mathrm{pH}$ in $\mathrm{CaCl}_{2}$; $8.6 \mathrm{mg} \mathrm{dm}^{-3}$ of P; $0.55 \mathrm{cmol}_{\mathrm{c}} \mathrm{dm}^{-3}$ of $\mathrm{K} ; 3.7 \mathrm{cmol}_{\mathrm{c}} \mathrm{dm}^{-3}$ of $\mathrm{Ca}$; $1.4 \mathrm{cmol}_{\mathrm{c}} \mathrm{dm}^{-3}$ of $\mathrm{Mg}$ and $48 \%$ of CEC saturation by bases.

Soybean was sown in a no-till system on October 23, 2013, on wheat straw, and on October 28, 2014, on black oat straw. The seeds were treated with Carboxin $\left(30 \mathrm{~mL}\right.$ a.i. $50 \mathrm{~kg}^{-1}$ of seeds) and Thiram (30 mL a.i. $50 \mathrm{~kg}^{-1}$ of seeds), and inoculated with Bradyrhizobium elkanii at the concentration of $5 \times 10^{9}$ $\mathrm{CFU} \mathrm{mL} \mathrm{m}^{-1}$ at the dose of $100 \mathrm{~mL} 50 \mathrm{~kg}^{-1}$ of seeds. The cultivar used in the experiment was NK7059 RR (Vmax RR), which has indeterminate growth habit, relative maturity group of 5.9 and compact architecture, being one of the cultivars most used in southern Brazil in the last decade.

Basal fertilization consisted of the application of $350 \mathrm{~kg}$ $\mathrm{ha}^{-1}$ of single superphosphate and $250 \mathrm{~kg} \mathrm{ha}^{-1}$ of potassium chloride in the 2013/14 growing season, and $122 \mathrm{~kg} \mathrm{ha}^{-1}$ of triple superphosphate and $250 \mathrm{~kg} \mathrm{ha}^{-1}$ of potassium chloride in the 2014/15 growing season, applied broadcast 10 days before sowing, with expected grain yield of $5000 \mathrm{~kg} \mathrm{ha}^{-1}$. Diseases, pest insects and weeds were controlled according to the technical recommendations for the crop (EMBRAPA, 2011). The data of rainfall and mean air temperature during the experimental periods are shown in Figure 1.

The experimental design was randomized blocks, with split plots and six replicates. In the plots $(10 \times 5 \mathrm{~m})$, four seeding rates $(150,300,440$ and 560 thousand seeds ha-1) were evaluated at spacing of $50 \mathrm{~cm}$ between rows. These seeding rates led to the following plant densities at harvest: 135, 235, 315 and 440 thousand plants ha ${ }^{-1}$ in the season of 2013/14, and 105, 210, 345 and 430 thousand plants ha ${ }^{-1}$ in the season of 2014/15. In the subplots $(5 \times 5 \mathrm{~m})$, two $\mathrm{N}$ fertilization doses $(0$ and 45 $\mathrm{kg} \mathrm{N} \mathrm{ha-1}$ ) were evaluated. The $\mathrm{N}$ source used was ammonium sulfate, applied broadcast without incorporation, when plants showed one to two trifoliate leaves. The evaluation area of the subplots was $4 \mathrm{~m}$ long and $1.5 \mathrm{~m}$ wide $\left(6 \mathrm{~m}^{2}\right)$.

In the 2013/14 season, the following variables were analyzed: leaf, stem and total shoot dry matter, leaf/stem dry matter ratio in the stages V5 and R5.1 and $\mathrm{N}$ contents in leaves and stems in the V5 stage. In the 2014/15 growing season, the following variables were evaluated: leaf, stem and total shoot dry matter, leaf/stem dry matter ratio in the V5 stage, SPAD index in the R5.3 stage and first pod height. In both seasons, final plant height, number of branches per plant and grain yield were evaluated.

For the evaluation of leaf, stem and total shoot dry matter, the plants contained in a $1-\mathrm{m}^{2}$ area per plot were cut, separated, placed in paper bags and dried in an oven at $65{ }^{\circ} \mathrm{C}$ until constant mass, with results expressed in $\mathrm{g} \mathrm{m}^{-2}$. Leaf/stem dry matter ratio was obtained through the division of total leaf dry matter by the total stem dry matter. $\mathrm{N}$ contents in leaves and
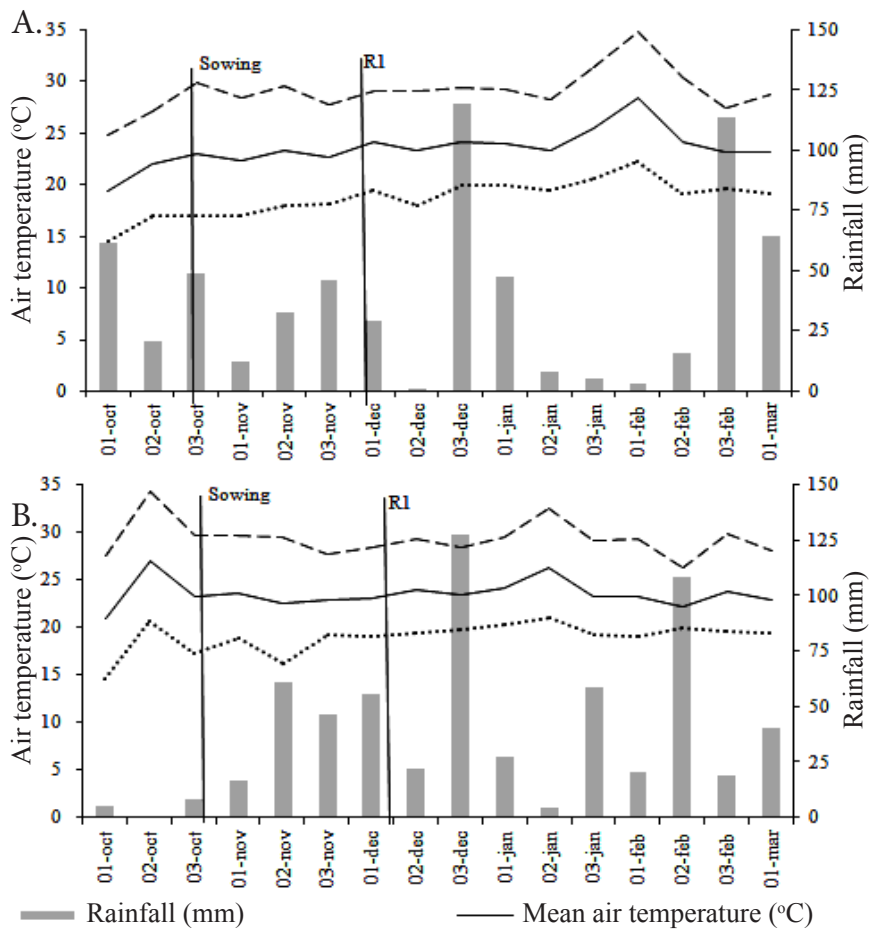

....... Minimum air temperature $\left({ }^{\circ} \mathrm{C}\right) \quad$ - - - Maximum air temperature $\left({ }^{\circ} \mathrm{C}\right)$

Figure 1. Rainfall and maximum, minimum and mean air temperature during the soybean development cycle in the growing seasons of 2013/2014 (A) and 2014/2015 (B) 
stems were determined by the Kjeldahl method (EMBRAPA, 1997). The SPAD index was determined using a Chlorophyll Meter SPAD-502 Plus (Konica Minolta ), in 10 leaves per plot, and the third leaf, from the apex to the base, was considered as the diagnostic leaf. The SPAD index was measured always in the central leaflet of the diagnostic leaf.

First pod height, plant height and number of branches per plant were evaluated in 10 plants per plot, collected in sequence. Grain yield was estimated in $\mathrm{kg} \mathrm{ha}^{-1}$, with moisture standardized at $13 \%$.

The data were subjected to analysis of normality and homoscedasticity using the tests of Shapiro-Wilk and Hartley, respectively, which indicated that data transformation was not necessary. Then, the data were subjected to analysis of variance and comparison of means by F test $(\mathrm{p} \leq 0.05)$ for the effect of mineral N. For the factor seeding rate, the final plant densities were considered and the data were subjected to second-degree polynomial regression analysis.

\section{Results AND Discussion}

In both seasons, there was no interaction between the experimental factors for all evaluated variables. Leaf, stem and total shoot dry matter in the V5 stage for both seasons increase with the increment in seeding rate (Tables 1 and 2). On the other hand, the leaf/stem dry matter ratio in the V5 stage was lower at the highest densities in both seasons, indicating that the increase in intraspecific competition promoted lower allocation of photoassimilates in the leaves, in detriment of the stem; hence, plant density significantly alters the structure of soybean canopy. At low densities, soybean plants form higher amount of leaves in relation to the stem, to intercept the light available in the community of plants, which occurs due to the decrease in the competition between plants for water, light and nutrients (Procópio et al., 2013).

Although plant density alters the partition of photoassimilates between leaves and stem, the $\mathrm{N}$ contents in these structures in the V5 stage were not influenced by the number of plants per area (Table 1). Luca \& Hungria (2014) observed that $\mathrm{N}$ contents in soybean shoots in the V4 stage did not vary as a function of plant density ( 40 and 320 thousand plants ha ${ }^{-1}$ ), but in the V5 stage the lowest plant density promoted the highest $\mathrm{N}$ contents in the pods. In the 2014/15 season, the increment in plant density reduced the SPAD index in the R5.3 stage (Table 2). Since this variable is correlated with leaf $\mathrm{N}$ content (Sant'Ana et al., 2010), these results suggest that plant density can alter the contents of $\mathrm{N}$ and chlorophyll in the leaves in more advanced stages of plant development.

In the $2013 / 14$ season, leaf, stem and total shoot dry matter in the R5.1 stage was not influenced by plant density (Table 1). This indicates that, with the advance in the soybean cycle, plants tend to compensate the lower density with greater growth per plant - a phenomenon called "phenotypic plasticity" (Holtz et al., 2014). Despite the use of a cultivar with indeterminate growth habit, short cycle and compact architecture, there was effect of the compensation of the lower amount of plants by the higher growth of each individual, maintaining the amount of dry matter per area unchanged in the beginning of the grain filling stage, however, the lower leaf/stem dry matter ratio at the highest plant densities remained until the R5.1 stage (Table 1).

In the 2013/14 season, plant height at harvest was not influenced by the densities (Table 1), however, in the

Table 1. Adjusted equations and means of soybean growth variables and grain yield at four seeding rates (means of two doses of nitrogen fertilization), in the 2013/2014 season

\begin{tabular}{|c|c|c|c|}
\hline Variables & Adjusted equation & $\mathbf{R}^{2}$ & CV (\%) \\
\hline Leaf dry matter in V5 ( $\left.\mathrm{g} \mathrm{m}^{-2}\right)$ & $\hat{Y}=14.673^{* \star}+0.0942^{* *} X$ & 0.97 & 24.0 \\
\hline Stem dry matter in V5 $\left(\mathrm{g} \mathrm{m}^{-2}\right)$ & $\hat{Y}=0.683^{\text {ns }}+0.0421^{\star *} X$ & 0.99 & 34.2 \\
\hline Leaf/Stem ratio in V5 & $\hat{Y}=4.661^{* *}-0.0041^{* *} X$ & 0.87 & 14.2 \\
\hline Total shoot dry matter in V5 $\left(\mathrm{g} \mathrm{m}^{-2}\right)$ & $\hat{Y}=15.356^{\star}+0.1364^{* \star} X$ & 0.99 & 25.5 \\
\hline Leaf N content in V5 (\%) & Mean $=4.53$ & & 6.0 \\
\hline Stem N content in V5 (\%) & Mean $=2.48$ & & 7.4 \\
\hline Leaf dry matter in R5.1 ( $\left.\mathrm{g} \mathrm{m}^{-2}\right)$ & Mean $=308.16$ & & 20.0 \\
\hline Stem dry matter in R5.1 ( $\left.\mathrm{g} \mathrm{m}^{-2}\right)$ & Mean $=248.36$ & & 22.9 \\
\hline Leaf/Stem ratio in $\mathrm{R} 5.1$ & $\hat{Y}=1.352^{* *}-0.0003^{*} X$ & 0.43 & 10.1 \\
\hline Total shoot dry matter in $R 5.1\left(\mathrm{~g} \mathrm{~m}^{-2}\right)$ & Mean $=651.85$ & & 21.0 \\
\hline Plant height (cm) & Mean $=94.18$ & & 8.8 \\
\hline Number of branches per plant & $\hat{Y}=4.908^{* *}-0.0109^{* *} X$ & 0.87 & 44.7 \\
\hline Yield $\left(\mathrm{kg} \mathrm{ha}^{-1}\right)$ & $\hat{Y}=1490.86^{\star \star}+12.68^{* *} X-0.0186^{\star *} X^{2}$ & 0.98 & 13.2 \\
\hline
\end{tabular}

${ }^{n s}$ Not significant; ** and *Significant at 0.01 and 0.05 probability levels, respectively, by the regression analysis

Table 2. Adjusted equations and means of soybean growth variables and grain yield at four seeding rates (means of two doses of nitrogen fertilization), in the 2014/2015 season

\begin{tabular}{|c|c|c|c|}
\hline Variables & Adjusted equation & $\mathbf{R}^{2}$ & CV (\%) \\
\hline Leaf dry matter in V5 $\left(\mathrm{g} \mathrm{m}^{-2}\right)$ & $\hat{Y}=13.729^{\text {ns }}+0.1754^{\star *} X$ & 0.96 & 31.9 \\
\hline Stem dry matter in V5 $\left(\mathrm{g} \mathrm{m}^{-2}\right)$ & $\hat{Y}=2.140^{\text {ns }}+0.0856^{* *} X$ & 0.99 & 33.4 \\
\hline Leaf/Stem ratio in V5 & $\hat{Y}=2.903^{\star *}-0.0014^{\star \star} X$ & 0.99 & 10.8 \\
\hline Total shoot dry matter in V5 $\left(\mathrm{g} \mathrm{m}^{-2}\right)$ & $\hat{Y}=15.869^{\text {ns }}+0.2611^{* \star} X$ & 0.97 & 32.0 \\
\hline SPAD index in R5.3 & $\hat{Y}=46.975^{* *}-0.0121^{* *} X$ & 0.99 & 5.1 \\
\hline Plant height (cm) & $\hat{Y}=81.599^{* *}+0.0463^{* \star} X$ & 0.85 & 12.1 \\
\hline First pod height (cm) & $\hat{Y}=8.683^{\star *}+0.0701^{\star *} X$ & 0.90 & 9.4 \\
\hline Number of branches per plant & $\hat{Y}=13.538^{* *}-0.0236^{* *} X$ & 0.95 & 34.1 \\
\hline Yield $\left(\mathrm{kg} \mathrm{ha}^{-1}\right)$ & Mean $=3905$ & & 8.4 \\
\hline
\end{tabular}

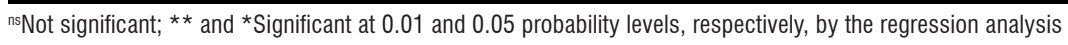


following season, plant height and first pod height increased linearly with the increment in density (Table 2). This is due to the greater competition between plants, determined by the alteration in the quality of the incident radiation, with an increment in the proportion of diffuse radiation in relation to global radiation, which favors higher stem elongation (Mauad et al., 2010; Pricinotto \& Zucareli, 2014).

In both seasons, the number of branches per plant decreased linearly as plant density increased. In the seasons of $2013 / 14$ and 2014/15, there were reductions of approximately 0.011 and 0.014 branches plant $^{-1}$ for every thousand plants $\mathrm{ha}^{-1}$ of increment in plant density. According to Procópio et al. (2013), the increase in branch number and size constitutes one of the main mechanisms that explain the high phenotypic plasticity of soybean in response to variations in plant density.

Soybean grain yield in the 2013/14 growing season varied quadratically with the increment in seeding rate, and the point of maximum technical efficiency occurred at approximately 340 thousand plants $\mathrm{ha}^{-1}$, below this density, there was probably lower utilization of environmental resources - water, light and nutrients -, because of the lower amount of plants, although at very high densities plant yield was limited by the intraspecific competition, causing the reduction of yield per individual to be more expressive than the increase in the number of plants per area. It is important to point out that, in the present study, the increase in seeding rate did not cause plant lodging, which could limit yield. Additionally, it is known that the increase in seeding rate leads to the increment of mortality rate (Tourino et al., 2002), which may reflect in yield reduction in a situation of high intraspecific competition. On the other hand, in the 2014/15 season, seeding rate did not influence grain yield, which demonstrates the phenotypic plasticity of the evaluated cultivar. In the 2014/15 growing season, there was higher water availability along the soybean cycle, compared with the previous season (Figure 1), which suggests that, under more favorable environmental conditions, there is lower variation of yield as a result of different seeding rates.

In the 2013/14 season, mineral $\mathrm{N}$ fertilization promoted increase in leaf dry matter and total shoot dry matter in the V5 stage (Table 3), which showed a behavior similar to that of the evaluations in the R5.1 stage; however, in the 2014/15

Table 3. Soybean growth variables and grain yield with and without nitrogen fertilization (means of four seeding rates), in the $2013 / 2014$ season

\begin{tabular}{lrrr}
\hline \multirow{2}{*}{ Variables } & \multicolumn{2}{c}{ Nitrogen } & CV \\
\cline { 2 - 3 } & \multicolumn{1}{c}{ Without } & \multicolumn{1}{c}{ With } & (\%) \\
Leaf dry matter in V5 $\left(\mathrm{g} \mathrm{m}^{-2}\right)$ & $37.76 \mathrm{~b}$ & $44.61 \mathrm{a}$ & 26.2 \\
Stem dry matter in V5 $\left(\mathrm{g} \mathrm{m}^{-2}\right)$ & $11.69 \mathrm{a}$ & $13.40 \mathrm{a}$ & 24.3 \\
Leaf/Stem ratio in V5 & $3.42 \mathrm{a}$ & $3.57 \mathrm{a}$ & 12.3 \\
Total shoot dry matter in V5 $\left(\mathrm{g} \mathrm{m}^{-2}\right)$ & $49.45 \mathrm{~b}$ & $58.01 \mathrm{a}$ & 25.2 \\
Leaf N content in V5 (\%) & $4.36 \mathrm{~b}$ & $4.70 \mathrm{a}$ & 7.5 \\
Stem N content in V5 (\%) & $2.29 \mathrm{~b}$ & $2.67 \mathrm{a}$ & 8.3 \\
Leaf dry matter in R5.1 $\left(\mathrm{g} \mathrm{m}^{-2}\right)$ & $294.43 \mathrm{a}$ & $321.89 \mathrm{a}$ & 17.4 \\
Stem dry matter in R5.1 $\left(\mathrm{g} \mathrm{m}^{-2}\right)$ & $229.90 \mathrm{~b}$ & $266.81 \mathrm{a}$ & 19.1 \\
Leaf/Stem ratio in R5.1 & $1.29 \mathrm{a}$ & $1.21 \mathrm{a}$ & 8.7 \\
Total shoot dry matter in R5.1 $\left(\mathrm{g} \mathrm{m}^{-2}\right)$ & $524.33 \mathrm{~b}$ & $588.70 \mathrm{a}$ & 17.7 \\
Plant height (cm) & $90.75 \mathrm{~b}$ & $97.62 \mathrm{a}$ & 7.7 \\
Number of branches per plant & $2.11 \mathrm{a}$ & $1.52 \mathrm{a}$ & 38.7 \\
Yield (kg ha-1) & $3258.00 \mathrm{a}$ & $3448.00 \mathrm{a}$ & 17.9 \\
\hline
\end{tabular}

Means followed by the same letters in the row do not differ at 0.05 probability level by $F$ test season, these variables, evaluated in the V5 stage, were not influenced by $\mathrm{N}$ fertilization, demonstrating that the effects of $\mathrm{N}$ fertilization, performed at the beginning of the vegetative stage, on the initial plant growth are highly dependent on environmental conditions. In this context, Purcell et al. (2004) observed that the production environment directly affects biological $\mathrm{N}$ fixation, mineralization of organic $\mathrm{N}$ and its absorption by soybean.

The leaf/stem dry matter ratio, evaluated in the stages V5 and R5.1 in the 2013/14 season and in the V5 stage in the $2014 / 15$ season, was not influenced by $\mathrm{N}$ fertilization (Tables 3 and 4 ), indicating that the partition of photoassimilates is not influenced by mineral $\mathrm{N}$ fertilization at the beginning of the cycle, even considering the $\mathrm{N}$ dose of $45 \mathrm{~kg} \mathrm{ha}^{-1}$, which is high in comparison to the $\mathrm{N}$ doses normally used at sowing (0 to $20 \mathrm{~kg} \mathrm{~N} \mathrm{ha}^{-1}$ ) (EMBRAPA, 2011).

$\mathrm{N}$ contents in leaves and stems in the V5 stage increased with the application of mineral N (Table 3), demonstrating that the applied $\mathrm{N}$ was absorbed and assimilated by plants; however, in the R5.3 stage of the 2014/15 growing season, there was no effect of $\mathrm{N}$ fertilization on the SPAD index. Luca et al. (2014) observed that soybean plants that received $200 \mathrm{~kg} \mathrm{~N} \mathrm{ha}^{-1} \mathrm{did}$ not show higher leaf $\mathrm{N}$ contents in the $\mathrm{R} 1$ stage, in relation to the treatments inoculated with Bradyrhizobium.

In the 2013/14 season, plant height at harvest was higher in the presence of mineral $\mathrm{N}$ (Table 3), however, in the following season, this variable and first pod height were not influenced by the mineral $\mathrm{N}$ fertilization (Table 4 ). Similar results were obtained by Silva et al. (2011), who reported that $\mathrm{N}$ fertilization of $24 \mathrm{~kg} \mathrm{ha}^{-1}$ promoted the highest value of plant height in the year with lower rainfall, compared with the year with higher rainfall.

In both growing seasons, the number of branches per plant was not altered by mineral $\mathrm{N}$ fertilization (Tables 3 and 4), therefore, it is supposed that such result was due to the adequate availability of $\mathrm{N}$ from biological fixation and mineralization of soil organic matter.

$\mathrm{N}$ fertilization did not promote increase in grain yield in any of both seasons (Tables 3 and 4). These results prove that the correct inoculation of seeds with $\mathrm{N}$-fixing bacteria (Hungria et al., 2006), along with the application of Cobalt and Molybdenum via seeds or leaves in the soybean crop (Dourado Neto et al., 2012), promotes adequate $\mathrm{N}$ nutrition to plants without the need for $\mathrm{N}$ application through mineral

Table 4. Soybean growth variables and grain yield with and without nitrogen fertilization (means of four seeding rates), in the 2014/2015 season

\begin{tabular}{|c|c|c|c|}
\hline \multirow{2}{*}{ Variables } & \multicolumn{2}{|c|}{ Nitrogen } & \multirow{2}{*}{$\begin{array}{l}\text { CV } \\
(\%)\end{array}$} \\
\hline & Without & With & \\
\hline Leaf dry matter in V5 $\left(\mathrm{g} \mathrm{m}^{-2}\right)$ & $58.17 \mathrm{a}$ & $64.92 \mathrm{a}$ & 20.2 \\
\hline Stem dry matter in V5 $\left(\mathrm{g} \mathrm{m}^{-2}\right)$ & $24.20 \mathrm{a}$ & $26.75 \mathrm{a}$ & 17.5 \\
\hline Leaf/Stem ratio in V5 & $2.47 \mathrm{a}$ & $2.51 \mathrm{a}$ & 7.7 \\
\hline Total shoot dry matter in V5 $\left(\mathrm{g} \mathrm{m}^{-2}\right)$ & $82.37 \mathrm{a}$ & $91.67 \mathrm{a}$ & 19.1 \\
\hline SPAD index in R5.3 & $43.49 \mathrm{a}$ & $43.81 \mathrm{a}$ & 5.0 \\
\hline Plant height (cm) & $92.76 \mathrm{a}$ & $95.71 \mathrm{a}$ & 10.1 \\
\hline First pod height (cm) & $19.63 \mathrm{a}$ & $20.35 \mathrm{a}$ & 10.1 \\
\hline Number of branches per plant & $2.29 \mathrm{a}$ & $2.26 \mathrm{a}$ & 28.3 \\
\hline Yield $\left(\mathrm{kg} \mathrm{ha}^{-1}\right)$ & $3937.00 \mathrm{a}$ & $3872.00 \mathrm{a}$ & 7.6 \\
\hline
\end{tabular}

Means followed by the same letters in the row do not differ at 0.05 probability level by $F$ test 
fertilization. Thus, regardless of the seeding rate, mineral $\mathrm{N}$ fertilization at the beginning of the development cycle, depending on the environmental conditions, can increase plant growth, but it does not reflect in increments in grain yield.

\section{Conclusions}

1. The growth of soybean plants per area is not affected by the interaction of seeding rate and mineral nitrogen fertilization.

2. In cultivar with indeterminate growth habit, short cycle and compact architecture, the increase in seeding rate from 150 to 560 thousand viable seeds ha ${ }^{-1}$ increases plant dry matter in the initial development stages and reduces leaf/stem dry matter ratio and the number of branches per plant.

3. The effect of mineral $\mathrm{N}$ fertilization on plant growth is variable between growing seasons, but does not increase grain yield even considering a wide variation of seeding rate.

\section{Literature Cited}

Balbinot Júnior, A. A.; Procópio, S. O.; Debiasi, H.; Franchini, J. C.; Panison, F. Semeadura cruzada em cultivares de soja com tipo de crescimento determinado. Semina: Ciências Agrárias, v.36, p.12151226, 2015. http://dx.doi.org/10.5433/1679-0359.2015v36n3p1215

Campo, R. J.; Araújo, R. S.; Hungria, M. Molybdenum-enriched soybean seeds enhance $\mathrm{N}$ accumulation, seed yield, and seed protein content in Brazil. Field Crops Research, v.110, p.219-224, 2009. http://dx.doi.org/10.1016/j.fcr.2008.09.001

Dourado Neto, D.; Dario, G. J. A.; Martin, T. N.; Silva, M. R.; Pavinato, P. S.; Habitzreiter, T. L. Adubação mineral com cobalto e molibdênio na cultura da soja. Semina: Ciências Agrárias, v.33, p.2741-2752, 2012.

EMBRAPA - Empresa Brasileira de Pesquisa Agropecuária. Manual de métodos de análise de solo. 2. ed. Rio de Janeiro: EMBRAPA, 1997. 212p.

EMBRAPA - Empresa Brasileira de Pesquisa Agropecuária. Tecnologias de produção de soja - Região Central do Brasil 2012 e 2013. 21. ed. Londrina: Embrapa Soja, 2011. 261p.

Holtz, V.; Couto, R. F.; Oliveira, D. G.; Reis, E. F. Deposição de calda de pulverização e produtividade da soja cultivada em diferentes arranjos espaciais. Ciência Rural, v.44, p.1371-1376, 2014. http:// dx.doi.org/10.1590/0103-8478cr20130783

Hungria, M.; Franchini, J. C.; Campo, R. J.; Crispino, C. C.; Moraes, J. Z.; Sibaldelli, R. N. R.; Mendes, I. C.; Arihara, J. Nitrogen nutrition of soybean in Brazil: Contributions of biological $\mathrm{N}_{2}$ fixation and $\mathrm{N}$ fertilizer of grain yield. Canadian Journal of Plant Science, v.86, p.927-939, 2006. http://dx.doi.org/10.4141/P05-098

Luca, M. J.; Hungria, M. Plant densities and modulation of symbiotic nitrogen fixation in soybean. Scientia Agricola, v.71, p.181-187, 2014. http://dx.doi.org/10.1590/S0103-90162014000300002

Luca, M. J.; Nogueira, M. A.; Hungria, M. Feasibility of lowering soybean planting density without compromising nitrogen fixation and yield. Agronomy Journal, v.106, p.2118-2124, 2014. http:// dx.doi.org/10.2134/agronj14.0234
Ludwig, M. P.; Dutra, L. M. C.; Lucca Filho, O. A.; Zabot, L.; Jauer, A.; Uhry, D. Populações de plantas na cultura da soja em cultivares convencionais e Roundup Ready ${ }^{\mathrm{TM}}$. Revista Ceres, v.58, p.305313, 2011. http://dx.doi.org/10.1590/S0034-737X2011000300010

Mauad, M.; Silva, T. L. B.; Almeida Neto, A. I.; Abreu, V. G. Influência da densidade de semeadura sobre características agronômicas na cultura da soja. Revista Agrarian, v.3, p.175-181, 2010.

Pricinotto, L. F.; Zucareli, C. Paclobutrazol no crescimento e desempenho produtivo da soja sob diferentes densidades de semeadura. Revista Caatinga, v.27, p.65-74, 2014.

Procópio, S. O.; Balbinot Júnior, A. A.; Debiasi, H.; Franchini, J. C.; Panison, F. Plantio cruzado na cultura da soja utilizando uma cultivar de hábito de crescimento indeterminado. Revista de Ciências Agrárias/Amazonian Journal of Agricultural and Environmental Sciences, v.56 p.319-325, 2013. http://dx.doi. org/10.4322/rca.2013.048

Procópio, S. O.; Balbinot Júnior, A. A.; Debiasi, H.; Franchini, J. C.; Panison, F. Semeadura em fileira dupla e espaçamento reduzido na cultura da soja. Revista Agroambiente, v.8, p.212-221, 2014. http://dx.doi.org/10.18227/1982-8470ragro.v8i2.1469

Purcell, L. C.; Rachid, S.; Sinclair, T. R. Soybean $\mathrm{N}_{2}$ fixation estimates, ureide concentration, and yield responses to drought. Crop Science, v.44, p.484-492, 2004. http://dx.doi.org/10.2135/ cropsci2004.4840

Roekel, R. J. van; Purcell, L. C. Soybean biomass and nitrogen accumulation rates and radiation use efficiency in a maximum environment. Crop Science, v.54, p.1189-1196, 2014. http://dx.doi. org/10.2135/cropsci2013.08.0546

Sant'Ana, E. V. P.; Santos, A. B.; Silveira, P. M. Adubação nitrogenada na produtividade, leitura SPAD e teor de nitrogênio em folhas de feijoeiro. Pesquisa Agropecuária Tropical, v.40, p.491-496, 2010. http://dx.doi.org/10.1590/S1983-40632010000400012

Santos, H. G.; Jacomine, P. K. T.; Anjos, L. H. C.; Oliveira, V. A.; Oliveira, J. B.; Coelho, M. R.; Lumbreras, J. F.; Cunha, T. J. F. Sistema brasileiro de classificação de solos. 2. ed. Rio de Janeiro: Embrapa Solos, 2006. 306p.

Silva, A. F.; Carvalho, M. A. C.; Schoninger, E. L.; Monteiro, S.; Caione, G.; Santos, P. A. Doses de inoculante e nitrogênio na semeadura da soja em área de primeiro cultivo. Bioscience Journal, v.27, p.404-412, 2011.

Silva, P. R. A.; Tavares, L. A. F.; Sousa, S. F. G.; Correia, T. P. S.; Riquetti, N. B. Rentabilidade na semeadura cruzada da cultura da soja. Revista Brasileira de Engenharia Agrícola e Ambiental, v.19, p.293-297, 2015. http://dx.doi.org/10.1590/1807-1929/ agriambi.v19n3p293-297

Souza, C. A.; Gava, F.; Casa, R. T.; Bolzan, J. M.; Kuhnem Júnior, P. R. Relação entre densidade de plantas e genótipos de soja Roundup Ready $^{\mathrm{TM}}$. Planta Daninha, v.28, p.887-896, 2010. http://dx.doi. org/10.1590/S0100-83582010000400022

Tourino, M. C. C.; Rezende, P. M.; Salvador, N. Espaçamento, densidade e uniformidade de semeadura na produtividade e características agronômicas da soja. Pesquisa Agropecuária Brasileira, v.37, p.1071-1077, 2002. http://dx.doi.org/10.1590/ S0100-204X2002000800004 